Н. Б. Есипова, В. А. Жежеря

Днепропетровский национальный университет

\title{
СЕЗОННАЯ ДИНАМИКА МИКРОБИОЛОГИЧЕСКИХ ПОКАЗАТЕЛЕЙ ВОДЫ р. ИНГУЛЕЦ И р. БЕРЕЗОВКА НА УЧАСТКАХ С РАЗНОЙ АНТРОПОГЕННОЙ НАГРУЗКОЙ
}

Проаналізовано сезонну динаміку мікробіологічних показників санітарного стану досліджуваних річок у весняно-осінній період. Проведене санітарне районування річок у межах м. Олександрія. Встановлено, що за показниками індексу лактозопозитивних кишкових паличок (ЛКП) найбільше забруднення води річок у більшості випадків спостерігалось у серпні.

\author{
N. B. Esipova, V. A. Zhezherya \\ Dnipropetrovsk National University
}

\section{SEASONAL DYNAMICS OF MICROBIOLOGICAL INDICES OF WATER IN THE INGULETS AND BEREZOVKA RIVERS UNDER DIFFERENT ANTROPOGENIC BURDEN}

The seasonal dynamics of microbiological indices of sanitary situation in Ingulets and Berezovka Rivers was analysed at spring-autumn period. The sanitary mapping of the rivers was done for the Alexandria area. In most cases maximal level of the rivers contamination by the lactose-positive E. coli index was found in August.

\section{Введение}

Загрязнение водоемов сточными водами приняло массовый характер и несет в себе опасность вспышек различных заболеваний, которые передаются водным путем. Кроме того, избыточное содержание органических веществ в воде приводит к возникновению антропогенной эвтрофикации водоемов. Наличие кишечной палочки в воде свидетельствует не только об антропогенном фекальном загрязнении, но и о высоком содержании органического вещества, которое возникает в результате отмирания гидробионтов, в основном фитопланктона и высшей водной растительности [8]. Ввиду сложности взаимоотношений гидробионтов в биоценозах часто бывает трудно определить самоочистительную способность водоемов. Как правило, патогенные микроорганизмы гибнут быстрее в водоемах, богатых гидробионтами [2].

Наибольшее содержание бактерий группы кишечной палочки (БГКП) в летний период 1991 года отмечено на поверхности вод у р. Малая Осиновка (20626 кл./л), что связано с влиянием сточных вод г. Байкальск. В зоне активного разбавления сточных вод в месте их выпуска число БГКП варьирует от 0 до 1812 кл./л. Высокий показатель индекса Escherichia coli обнаружен в устьях рек Большая Осиновка (2750 кл./л), Солзан (1250 кл./л), Харлахта (937 кл./л), Бабха (1375 кл./л), Утулик (1962 кл./л), Похабиха (2750 кл./л). Высокое загрязнение прибрежных вод БГКП обнаружено в районе бухты Большие Коты (2926 кл./л) [7]. Весной в р. Кура числен-

(C) Н. Б. Есипова, В. А. Жежеря, 2008 
ность БГКП увеличивалась до 6,8 млн. кл./л. Отмечено наибольшее количество БГКП летом в июле, когда численность доходила в реке до 21 млн. кл./л [1]. Индекс E. coli в Березанском лимане в течение года колебался от 1,0 до 25 тыс. кл./л и был выше весной и осенью, минимальным - летом (по-видимому, в связи с различной интенсивностью процессов самоочищения вод и солнечной радиации по сезонам) [10].

Содержание БГКП в Кураховском водохранилище определяли на протяжении 1967-1968 годов и выражали индексом E. coli, величина которого изменялась от 0,9 до 140 тыс. кл. /л. На всех исследуемых участках наибольшее количество этих бактерий отмечено летом, наименьшее - зимой. Повышение температуры на $8^{\circ} \mathrm{C}$ способствовало возрастанию величины индекса E. coli в 65 раз по сравнению с контролем [6].

Численность БГКП в водоеме-охладителе Курской АЭС во время большинства съемок была довольно высокой (до 273,5 тыс. кл./л). Как правило, наибольшие значения численности БГКП наблюдались в зоне максимального подогрева. В районе сброса численность БГКП была относительно высока. Далее по ходу циркуляции течения наблюдалось значительное снижение количества этих микроорганизмов. В районе г. Курчатов численность БГКП увеличивается, что обусловлено загрязнением водоема-охладителя с территории города. Локальное увеличение численности БГКП неоднократно отмечалось также в районе выхода промливневой канализации [11]. Максимальная величина индекса E. coli (порядка 30,0-60,0 тыс. кл./л) обнаружена у населенных пунктов Центрального и Бугского районов весной и осенью, что свидетельствует о высоком уровне антропогенного загрязнения, связанного с поступлением бытовых стоков [9].

Цель нашей работы - оценить сезонную динамику микробиологических показателей и провести санитарное районирование рек Ингулец и Березовка в черте города Александрия (Кировоградская область).

\section{Материал и методы исследований}

Река Ингулец протекает с северо-запада на юго-восток через центр Александрии, поделив город на две части. Река Березовка протекает с северо-востока на юго-запад и впадает в р. Ингулец. В районе исследования Ингулец и Березовка неглубокие и маловодные. Основным источником их питания являются талые воды. По классификации М. И. Львовича, это реки преимущественно снегового питания, у которых доля талых вод превышает 50 \% годового стока. На долю подземного питания приходится около $30 \%$ годового стока. Доля питания рек за счет дождевых вод очень мала и не превышает 10 \%. По составу вода реки Ингулец гидрокарбонатно-кальциевая. Минерализация воды в верхней части Ингульца составляет 500-1000 мг/л [3]. По данным СЭС г. Александрия, вода р. Ингулец и р. Березовка имеет следующие гидрохимические показатели в летнеосенний период: прозрачность - 4-20 см, $p H-7,0-10,5$, содержание кислорода - 5,011,6 мг/л, жесткость - 4,2-11,3 мг-экв./л, минерализация - 403-990 мг/л.

В данной работе использовались классические методы определения численности сапрофитной микрофлоры, которая инкубировалась при $+37^{\circ} \mathrm{C}$ и $+22{ }^{\circ} \mathrm{C}$, индекса ЛКП и $E$. coli, стафилококков, энтерококков, определение числа бляшкообразующих единиц (БОЕ) фагов кишечной палочки, шигелл и сальмонелл, согласно ГОСТ 2285-81 «Методические указания по санитарно-микробиологическому исследованию воды из поверхностных водоемов». О степени загрязнения воды водоемов сточными водами хозяйственно-фекального характера судили по значению индекса ЛКП и E. coli.

В зависимости от характера антропогенной нагрузки при отборе проб район исследования условно разделили на три зоны: санаторно-курортную (точки 1-3), зо- 
ну городских пляжей (точки 4-7), зону сброса сточных вод (точки 8-10). Отбор проб проводили в восьми точках на р. Ингулец, и двух - на р. Березовка. Все точки отбора проб воды находятся в местах массового купания (за исключением точки 10, расположенной в районе сброса сточных вод г. Александрия). Пробы отбирали с мая по сентябрь 2003-2005 годов.

Согласно ГОСТ 2285-81, содержание БОЕ фагов кишечных палочек более 1000 кл./л в воде водоема представляет эпидемическую опасность в отношении кишечных вирусных инфекций. Сигнальным значением для регламентации нагрузки на зону купания является наличие индекса стафилококков свыше 100 кл./л. При индексе энтерококков свыше 500 кл./л предполагается поступление свежего фекального загрязнения и опасности в эпидемическом отношении [4]. Показатели индекса ЛКП не должны превышать 10000 кл./л, если вода будет использоваться для централизованного или нецентрализованного хозяйственно-питьевого водопотребления и не более 5000 кл./л для рекреационных целей [5].

\section{Результаты и их обсуждение}

Наши исследования свидетельствуют, что во всех трех зонах такие микробиологические показатели как индекс стафилококков, энтерококков, число БОЕ фагов кишечной палочки находились в пределах санитарных норм и не имели выраженной динамики, вода не содержала шигелл и сальмонелл. Зато показатели индекса ЛКП и E. coli имели выраженную динамику.

В санаторно-курортной зоне г. Александрия в 2003 году индекс ЛКП колебался в пределах от 3000 до 43000 кл./л, в 2004-м - от 300 до 3600 кл./л, а в 2005-м - от 3600 до 460000 кл./л. Проведя анализ данных за 2003 год, можно сделать вывод, что наибольшее загрязнение воды в санаторно-курортной зоне происходило в августе (индекс ЛКП составил 43000 кл./л). В 2004 году наибольшее загрязнение воды данной зоны наблюдалось в июне, августе и сентябре (индекс ЛКП составил 3600 кл./л). В 2005-м наибольшее загрязнение воды данной зоны также наблюдалось в августе (индекс ЛКП составил 460000 кл./л). При анализе максимальных показателей индекса ЛКП за три года наблюдений в санаторно-курортной зоне нами установлено, что в 2003-м он превышал санитарные нормы в 8,6 раза; в 2004-м не выходил за пределы санитарных норм, а в 2005-м превышал санитарные нормы в 92 раза.

В зоне городских пляжей в 2003 году индекс ЛКП находился в пределах от 1200 до 460000 кл./л, в 2004 году - от 300 до 240000 кл./л, а в 2005-м - от 3600 до 150000 кл./л. Проведя анализ данных индекса ЛКП за 2003 год, можно сделать вывод, что максимальное загрязнение речной воды в зоне городских пляжей происходило в августе (индекс ЛКП составил 460000 кл./л). В 2004 году максимальное загрязнение речной воды наблюдалось в июле (индекс ЛКП составил 240000 кл./л на городском пляже). В 2005 году максимальное загрязнение речной воды происходило в августе (индекс ЛКП составил 150000 кл./л). При анализе максимальных показателей индекса ЛКП за три года наблюдений в зоне городских пляжей установлено, что в 2003 году он превышал санитарные нормы в 92 раза, в 2004-м - в 48, а в 2005-м - в 30 раз.

В районе сброса сточных вод города в 2003 году индекс ЛКП выше места спуска сточных вод находился в пределах от 2300 до 460000 кл./л, тогда как ниже - от 13000 до 930000 кл./л. В 2004-м индекс ЛКП выше места спуска сточных вод находился в пределах от 11000 до 73000 кл./л, а ниже - от 20000 до 1600000 кл./л. В 2005 году индекс ЛКП выше места спуска сточных вод колебался в пределах от 7300 до 23000 кл./л, а ниже - от 21000 до 93000 кл./л. Таким образом, показатели ин- 
декса ЛКП ниже места спуска сточных вод превышают значения индекса ЛКП, определенные выше места спуска сточных вод. Это связано с действием на речную воду сточных вод г. Александрия. В 2003 году максимальное загрязнение речной воды, судя по показателям индекса ЛКП, происходило в июле, в 2004-м - также в июле, тогда как в 2005 году - в июне. При анализе максимальных показателей индекса ЛКП за три года наблюдений в зоне сброса сточных вод нами установлено, что в 2003-м он превышал санитарные нормы выше места сброса сточных вод в 92 раза, а ниже - в 186 раз; в 2004-м соответственно - 14,6 и 320 раз; в $2005-$ - $-4,6$ и 18,6 раза.

\section{Заключение}

В санаторно-курортной зоне отмечено, что за три года наблюдений максимальное загрязнение речной воды происходит в августе, что связано с повышением температуры воды. В зоне городских пляжей дважды пик максимального загрязнения воды отмечался в августе (2003 и 2005 гг.), а в 2004 году - в июле. В зоне сброса сточных вод пик максимального загрязнения воды отмечался в июле 2003 и 2004 годов и в июне 2005 года, что связано не только с повышением температуры, но и с режимом сброса сточных вод.

При анализе микробиологических показателей трех зон наблюдения наименьшее загрязнение имела санаторно-курортная, затем зона городских пляжей, а наибольшее загрязнение наблюдалось в районе сброса сточных вод. В большинстве случаев максимальное загрязнение речной воды происходило в августе, что больше всего связано с повышением температуры воды, с отмиранием фитопланктона и высшей водной растительности.

\section{Библиографические ссылки}

1. Алиев С. Н. Микрофлора реки Куры и ее роль в процессах самоочищения: Автореф. дис. ... канд. биол. наук. - К., 1980. -24 с.

2. Вербина Н. М. Гидромикробиология с основами общей микробиологии. - М.: Пищевая промышленность, 1980. -288 с.

3. Герасимов И. П. Природные условия и естественные ресурсы СССР. Украина и Молдавия. - М.: Наука, 1972. -439 с.

4. ГОСТ 2285-81. Методические указания по санитарно-микробиологическому исследованию воды из поверхностных водоемов. - М.: Изд-во стандартов, 1981. -30 с.

5. Государственные санитарные правила планирования и застройки населенных пунктов, утвержденные Приказом по Министерству здравоохранения Украины от 19.06.1996 г. К.: 1996. -59 c.

6. Ленчина Л. Г. Микробиологическая характеристика некоторых водоемов-охладителей тепловых электростанций юга Украины: Автореф. дис. ... канд. биол. наук. - К., 1980. - 23 с.

7. Максимов В. В. Микробиология крупных рек Байкала и их приустьевых акваторий: Автореф. дис. ... канд. биол. наук. - Иркутск, 1995. -25 с.

8. Романенко В. Д. Основы гидроэкологии. - К.: Обереги, 2001. - 728 с.

9. Россова Э. Я. Бактериопланктон Днепровско-Бугского лимана / Э. Я. Россова, Ю. С. Гаран // Вопросы гидробиологии нижнего Днепра и лиманов Северного Причерноморья. - К.: Наукова думка, 1978. - 128 с.

10. Россова Э. Я. Современное состояние бактериопланктона Березанского лимана / Э. Я. Россова, Ю. С. Гаран, Г. Н. Шахман // Гидробиологические исследования пресных вод. - К.: Наукова думка, 1985. - 160 с.

11. Суздалева А. Л. Бактериопланктон водоемов-охладителей Курской и Калининской АЭС: Автореф. дис. ... канд. биол. наук. - М., 1996. - 23 с. 